\title{
Usefulness of the evaluation of the titres of glutamic acid decarboxylase autoantibody (GADAs) in patients with diabetes
}

\author{
Otto-Buczkowska $\mathrm{E}^{1}$, Jainta $\mathrm{N}^{2^{*}}$, Stańczyk J ${ }^{3}$ \\ ${ }^{1}$ Medical Specialist Centre in Gliwice, Poland \\ ${ }^{2}$ Medical University of Silesia in Katowice, Poland \\ ${ }^{3}$ Medical Specialist Centre in Zawiercie, Poland
}

Received: March 12,2019; Accepted: March 22,2019; Published: April 4, 2019

*Corresponding author : Jainta N. MD, Medical University of Silesia in Katowice, Poland; E-mail: nataliajainta@gmail.com

\begin{abstract}
Diabetes mellitus is a group of diseases characterized by chronic increase of glucose level. Recent years brought much progress in understanding its complex pathogenesis. The classification that has been valid since 1999 which divided diabetes mellitus to type 1, type 2 , gestational, and a group of "other specific syndromes." has become inadequate to current knowledge.

The differential diagnostics of types of the diseases is playing an increasing role in diabetology, as it enables selection of optimal treatment methods, as well as, the assessment of prognosis referring to the diabetes course and complications occurrence. One of the indicators enabling such an assessment is the determination of the titres of autoantibodies, among them anti-GAD. Increasing the titre of these autoantibodies indicates an autoimmune basis for the development of diabetes and the need for insulin therapy in its treatment.
\end{abstract}

Materials and methods: This paper presents a retrospective analysis of 7 patients with diabetes diagnosed initially as type 2 diabetes.

The determination of the level of C-peptide and the titres of autoantibodies carried out in subsequent years allowed us to verify the diagnosis of type diabetes.

Conclusion: This analysis indicates the importance of determining the level of C-peptide and the titres of autoantibodies for the early diagnosis of autoimmune diabetes mellitus.

Key words: Diabetes mellitus; type 1 diabetes; type 2 diabetes; Latent autoimmune diabetes in adults (LADA); anti-GAD autoantibodies; C-peptide.

\section{Introduction}

Attempts to differentiate diabetes types have a long history. Initially, this division was based on the assessment of patients' age. As the knowledge and diagnostic possibilities were extended in the 1930s, this division was based on the assessment of insulin sensitivity. In subsequent years, this report was based on the assessment of beta cell function and insulin secretion. The next indicator was the assessment of insulin resistance. Recent years have brought a definite blurring of the borderline between the current division into type 1 and type 2 diabetes. [1,2,3]

An indicator that was used to differentiate these types of diabetes was the measurement of the titre of autoantibodies. [4]

Glutamic acid decarboxylase autoantibody (GADAs) in patients with diabetes

Anti-GAD antibodies (GADA: glutamic acid decarboxylase antibody) is one of the types of autoantibodies directed against the Langerhans islands located in the pancreas. As a result of the autoimmune effect of anti-GAD antibodies on the islets of the pancreas, they are destroyed and the deficit of endogenous insulin is caused.

The presence of elevated titer of these autoantibodies was associated with the diagnosis of type 1 diabetes in young patients. $[5,6]$

It was later found that the elevation of this titer also occurs in LADA (latent autoimmune diabetes in adults), i.e. in autoimmune diabetes developing in young adult patients. $[7,8,9,10,11]$

We now know that the increase in anti-GAD titer also occurs in other groups of patients, including patients with type 2 diabetes. [12]

However, studies conducted by Canadian diabetologists have shown that in the group of patients diagnosed with type 2 diabetes, there are differences in the course of diabetes and in the results of treatment between those who have anti-GAD autoantibodies compared to those who did not show these autoantibodies. [13]

This is associated with increased insulin resistance and $\beta$ cell dysfunction. Patients with elevated levels of anti-GAD autoantibodies have been found to be more sensitive to insulin assessed based on measurement fasting insulin concentration and HOMA-IR.

These differences in the clinical picture and susceptibility to treatment in groups of patients displaying elevated levels of anti-GAD autoantibodies compared with those patients who 
have low titres of autoantibodies indicate the justification for the determination of this titre in the widest possible group of patients with diabetes. It is known that insulin therapy should be used as early as possible in groups of patients with elevated anti-GAD titres. Many authors point out that the early inclusion of insulin therapy can slow down the process of autoimmune destruction of $\beta$ cells. $[14,15]$

Thereis a lot of evidence thatinsulin has an immunomodulatory effect in addition to the substitution effect, and that it inhibits the self-destruction of pancreatic islets.

It is considered erroneous to use sulfonylurea derivatives in these patients, which can activate autoimmune processes and accelerate the processes of $\beta$-cell destruction. [7.10]

\section{The use of anti-GAD titer determination in disease states other than diabetes}

Additionally, it is worth mentioning that currently the measurement of the titre of these antibodies is more and more often performed in neurological patients, eg in differentiating the types of epilepsy. [16] And also inflammatory states of the brain tissue. [17]

There have been reports of the appearance of elevated antiGAD in patients with cancer, in whom diabetes occurred as a consequence of the induction of immunotherapy. [18, 19]

\section{Discussion}

Current knowledge allows to determine that the differentiation of diabetes types known since 1999 is now out of date. The revision of the current classification is crucial.

The introduction of immunological and genetic research has broadened knowledge on the topic of etiopathogenesis of glucose metabolism disorders and orders a revision that can be expected in the upcoming years. $[20,21,22]$

One of the elements forming the basis for differentiation is the interview and assessment of the dynamics of the development of disease symptoms. Currently, it is known beyond any doubt that this is a criterion in fact, in many cases it is true, but also not so rarely fails, as the dynamics of the development of diabetes symptoms does not always allow for the differentiation of its types.

The age of the patient formerly determined the classification of the disease. Now we know that this criterion also does not allow for the differentiation of the types of diabetes. When differentiating types of diabetes, it is very important to be able to determine the level of C-peptide, although it is known that this criterion also cannot be conclusive because the level of C-peptide depends on many factors, including the duration of diabetes.

Currently, a very important indicator allowing the selection of the correct therapy and the prediction of the clinical course of diabetes is the determination of the titre of antipeptide autoantibodies including glutamic acid decarboxylase autoantibodies (anti-GAD) A comprehensive multicentre discussion of the assessment of GAD autoantibody versus clinical picture and response to treatment was presented by Zinman et al. [13]

In the group of 4,034 diabetic patients diagnosed as type 2 diabetes in the GAD-positive subjects, the mean fasting insulin level was $11 \%$ lower than in the GAD-negative individuals. Determination of a / GAD titer is recommended when suspecting autoimmune types of diabetes: type 1 and type LADA diabetes. $[8,23,24]$

Recently, attention has been paid to differences in the course of diabetes depending on the type of autoantibodies found: full-length GAD65 autoantibodies (f-GADA) and N-terminally truncated (amino acids 96-585) GAD65 autoantibodies (t-GADA). [25]

According to these authors the presence of autoantibodies of $\mathrm{N}$-terminally truncated GAD65 (t-GADA), is associated with the clinical phenotype of autoimmune type 1 diabetes and predicts insulin therapy. These patients present early occurrence and high titre of autoantibodies. In this group of patients, there is usually a clear decrease in the level of C-peptide [26].

Currently, the indications for the determination of the antiGAD titre have significantly increased. Such labeling is important for the suspicion of MODY diabetes, which clinical picture may suggest diabetes with autoimmune disease. It is also increasingly used in patients with diabetes classified primary as type 2 diabetes. Assessing the a / GAD titer in these cases allows for the verification of the therapy undertaken and the decision on the earlier inclusion of insulin therapy, as well as the decision to exclude sulphonylurea from treatment.

\section{Materials and Methods}

The retrospective analysis was subjected to a several-year course of disease in 7 patients aged from 34 to 78 years. Initially, diabetes in patients diagnosed as type 2 diabetes was the result of not carrying out the C-peptide level determination and the titre of autoantibodies against islet cell antigens. Performing these tests allowed to verify and diagnose diabetes with autoimmune background.

Data on patients. The table presents selected data for 7 patients with GAD autoantibodies (Table 1)

\section{Cases}

Patient 1. The diagnosis of diabetes was accompanied by polyuria, weight loss, glycemia of about $300 \mathrm{mg} / \mathrm{dl}$. The patient was treated for one year with oral antidiabetic agents. Due to the finding of an increased anti-GAD titre and a reduced level of the C-peptide insulin therapy was included. Clinical picture and course of the disease spoke for the diagnosis of type LADA diabetes

Patient 2. Initially, the patient was diagnosed with type 2 diabetes. After 2 months against the increase in glycemia to 300 $\mathrm{mg} / \mathrm{dl}$, the patient was referred to the hospital, where insulin therapy was included. Patient with numerous complications: ischemic heart disease ( $\mathrm{CABG}$, coronary artery bypass graft), hypertension arterialis, chronic obstructive pulmonary disease. 


\begin{tabular}{|c|c|c|c|c|c|c|c|c|}
\hline Case & $\begin{array}{c}\text { Age at } \\
\text { diagnosis }\end{array}$ & $\begin{array}{l}\text { Sex } \\
\text { M/F }\end{array}$ & $\begin{array}{l}\text { Visit } \\
\text { year }\end{array}$ & $\begin{array}{c}\text { BMI } \\
\mathrm{kg} / \mathrm{m}^{2}\end{array}$ & $\begin{array}{c}\text { HbA1c } \\
\%\end{array}$ & $\begin{array}{l}\text { Measure } \\
\text { GADA } \\
\text { IU/ml }\end{array}$ & $\begin{array}{c}\text { C-peptyd } \\
\text { ng/ml }\end{array}$ & Therapy \\
\hline 1 & 52 & $\mathrm{~F}$ & $\begin{array}{l}2012 \\
2013 \\
2014 \\
2015\end{array}$ & 21 & $\begin{array}{l}6.5 \\
7.7 \\
6.9\end{array}$ & 57.6 & 0.79 & $\begin{array}{c}\text { Gliclazide MR } 30 \\
+ \text { metformin } \\
\text { Insulin glulizine before meals } 2 \times 2 j+\text { Insulin glargine } 8 \mathrm{j} \\
\text { Insulin glulizine } 2 \times 4 \mathrm{j}+\text { Insulin glargine } 15 \mathrm{j} \\
\text { Insulin glulizine } 2 \times 4-6 \mathrm{j}+\text { Insulin glargine } 15 \mathrm{j}\end{array}$ \\
\hline 2 & 55 & M & $\begin{array}{l}2017 \\
2018\end{array}$ & 21,4 & $\begin{array}{l}7.9 \\
7.8\end{array}$ & 522 & 0.57 & $\begin{array}{c}\text { Insulin isophanum biphasicum M } 302 \times 22-26 j \\
\text { Insilin human neutral before meals } 2 \times 3-5 j+\text { Insulin isophanum } \\
\text { biphasicum M } 3015 \mathrm{j}\end{array}$ \\
\hline 3 & 52 & M & $\begin{array}{l}2005 \\
2011 \\
2012 \\
2013 \\
\\
2015 \\
\\
2016 \\
\\
2018\end{array}$ & $\begin{array}{c}24.9 \\
\\
\\
22 \\
21.3 \\
23.2\end{array}$ & $\begin{array}{l}7.1 \\
5.8 \\
6.7 \\
6.85\end{array}$ & 1333 & 0.82 & $\begin{array}{c}\text { Glimepiride 2mg } \\
\text { Glimepiride 2mg + metformin SR } 1000 \mathrm{mg} \\
\text { Glimepiride 2mg } \\
+ \text { metformin SR } 1000 \mathrm{mg} \\
\text { Glimepiride } 1 \mathrm{mg}+\text { metformin XR } 2000 \mathrm{mg} \\
\text { Glimepiride } 1 \mathrm{mg}+\text { metformin XR } 2000 \mathrm{mg} \\
\text { Insuman Rapid 2-4 } \mathrm{j} \text { before meals + Insulin glargine 6j } \\
\text { Insuman Rapid 2-4 j before meals + Insulin glargine } 6 \mathrm{j}\end{array}$ \\
\hline 4 & 50 & $\mathrm{~F}$ & $\begin{array}{l}2009 \\
2010 \\
2012 \\
2013 \\
2016 \\
2017 \\
2017 \\
2018\end{array}$ & $\begin{array}{r}22.5 \\
\\
\\
\\
25\end{array}$ & $\begin{array}{l}6.4 \\
7.0 \\
7.4 \\
6.8 \\
6.8 \\
6.6 \\
6.1 \\
7.1\end{array}$ & $>2000$ & 0.9 & $\begin{array}{l}\text { Glibenese GITS } 5 \mathrm{mg} \\
\text { Glibenese GITS } 5 \mathrm{mg}+\mathrm{NPH} \text { insulin } 6-8 \mathrm{j} \\
\text { Glibenese GITS } 5 \mathrm{mg}+\mathrm{NPH} \text { insulin } 10 \mathrm{j} \\
\text { Aspart before meals } 2-4 \mathrm{j}+\text { glargine } 6-8 \mathrm{j} \\
\text { Aspart before meals } 6-10 \mathrm{j}+\mathrm{NPH} \text { insulin } 15 \mathrm{j} \\
\text { Aspart before meals } 6-10 \mathrm{j}+\mathrm{NPH} \text { insulin } 20 \mathrm{j} \\
\text { Aspart before meals } 6-10 \mathrm{j}+\text { Insulin glargine } 20 \mathrm{j} \\
\text { Aspart before meals } 6-10 \mathrm{j}+\mathrm{NPH} \text { insulin } 20 \mathrm{j}\end{array}$ \\
\hline 5 & 34 & M & $\begin{array}{l}2015 \\
2015 \\
2016 \\
2016 \\
\\
2017 \\
2018 \\
\end{array}$ & $\begin{array}{l}30.5 \\
30.7\end{array}$ & $\begin{array}{l}10 \\
6.1 \\
8.4 \\
7.5\end{array}$ & 45.4 & 1.0 & $\begin{array}{c}\text { Insulin isophanum biphasicum } 252 \times 18-20 \mathrm{j} \\
\text { Insulin glulizyne before meals } 2-4 \mathrm{j}+\text { glargine } 6-8 \mathrm{j} \\
\text { Insulin glulizyne before meals } 2-4 \mathrm{j}+\text { Insulin glargine } 6-8 \mathrm{j} \\
\text { Insulin glulizyne before meals } 2-4 \mathrm{j}+\text { Insulin glargine } 6-8 \mathrm{j} \\
\text { Insulin glulizyne before meals } 10-12 \mathrm{j}+\text { Insulin glargine } 14-18 \mathrm{j} \\
\text { Insulin glulizyna before meals } 10-12 \mathrm{j}+\text { Insulin glargine } 18-22 \mathrm{j}\end{array}$ \\
\hline 6 & 78 & $\mathrm{~F}$ & $\begin{array}{l}2011 \\
2013 \\
2014 \\
2015 \\
2016 \\
2018\end{array}$ & 19.7 & $\begin{array}{l}5.5 \\
5.4 \\
5.8 \\
5.9 \\
6.0\end{array}$ & $>2000$ & 1.9 & $\begin{array}{c}\text { diet } \\
\text { Gliclazide MR } 30 \\
\text { Gliclazide MR } 30 \\
\text { Gliclazide MR } 30 \\
\text { Gliclazide MR } 30 \\
\text { Novo Mix } 302 \times 4-6 \mathrm{j}+\text { Aspart } 2 \mathrm{j}\end{array}$ \\
\hline 7 & 72 & M & $\begin{array}{l}2016 \\
2016 \\
2017 \\
2018\end{array}$ & 29.7 & $\begin{array}{l}8.4 \\
8.5 \\
8.5\end{array}$ & $>2000$ & 0.57 & $\begin{array}{l}\text { Aspart } 8-14 j \text { before meals } \\
+ \text { NPH insulin } 4 j+\text { metformin } 3 \text { X500 mg } \\
\text { Aspart before meals } 1 \times 10 j+2 \times 5 j+N P H \text { insulin } 10 j \\
\text { Aspart before meals }+ \text { NPH insulin } 14 j \\
\text { Aspart before meals } 1 \times 10-12 j+2 \times 5 j+\text { Abasaglar } 16 j\end{array}$ \\
\hline
\end{tabular}


A high titre of anti-GAD autoantibodies and a very significantly reduced level of $\mathrm{C}$-peptide were found, which indicated the diagnosis of LADA-type diabetes

Patient 3. Diabetes recognized as type 2, treated for 10 years with oral medications. It was not until 11 years after the diagnosis of diabetes that the determination of the titre of autoantibody anti-GAD was made, it was found to be very high. At the same time, the level of C-peptide was reduced. Clinical picture, high antibody titres and low levels of C-peptide indicated diagnosis of LADA type.

Patients 4. Diabetes diagnosed initially as type 2. In the first year, treated with oral medications, in the second year following the diagnosis, basal insulin was added. In the fourth year of the disease a very high level of anti-GAD autoantibodies and a level of peptide $\mathrm{C}$ were at the lower limit of the norm. LADA diabetes was diagnosed and intensive insulin therapy was included.

\section{Comment on cases $1,2,3,4$}

Age at diagnosis 50-55 years; observation period of 6-13 years; BMI 21-25; HbA1c ; HbA1c 5.8 - $7.7 \%$; GADA levels 57.6 - > $2000 \mathrm{IU} / \mathrm{ml}$; C-Peptide levels $0.57-0.9 \mathrm{ng} / \mathrm{ml}$

It seems that in the 4 cases presented, the diagnosis should be made earlier. The relatively young age of the patients, the lean body structure, the absence of a family history of diabetes mellitus should have led to the earlier identification of autoantibody and the level of C-peptide. This would allow to diagnose diabetes with autoimmune background. [7,10,11]

Patient 5. He is the youngest patient in the presented group. Shows the features of the metabolic syndrome, presents a very high body weight (BMI $28,4-30,7 \mathrm{~kg} / \mathrm{m} 2$ ). At the time diabetes was manifested in the blood glucose $300-400 \mathrm{mg} /$ dl (16.7-22.1 mmol/l). Initially, type 2 diabetes was diagnosed, and metformin was included. After 4 weeks, the condition deteriorated, polydipsia, polyuria, weight loss $8 \mathrm{~kg}$. Diabetes type 1 was diagnosed. Initial insulin mix was introduced, followed by intensive insulin therapy.

In the second year of the disease, the anti-GAD autoantibody titres were determined, which showed a slightly elevated titer. The level of C-peptide was within normal limits. For the next three years intensive therapy was maintained. This probably resulted in further weight gain (BMI $30,7 \mathrm{~kg} / \mathrm{m} 2$ ).

It seems that the diagnosis of type of diabetes requires verification. Consider whether or not it is type 2 diabetes in a patient with metabolic syndrome with anti-GAD antibodypositive or very slowly developing LADA diabetes. [27]

The Chinese authors suggest differentiation of LADA-type diabetes as LADA-type 1; while those with lower GADA titer and having clinical and metabolic phenotypes of type 2 diabetes are classified as LADA-type 2. [28]

The final classification would require longer observation, subsequent determinations of the anti-GAD titre, and a series of additional tests. [29,30,31]
In this case determining the final diagnosis would require further research. In the current situation, it seems advisable to consider reducing the insulin dose and try to include drugs from the groups GLP-1 analog or SGLT2 Inhibitors.

Patient 6. At the time of diagnosis of diabetes, the patient was 78 years old, very low body weight, showed vitiligo and kidney stones .

Type 2 diabetes was diagnosed and oral medications were included. In the seventh year of the disease, in the presence of hyperglycaemia $(200-235 \mathrm{mg} / \mathrm{dl} ; 11,2-13,1 \mathrm{mmol} / \mathrm{l})$, the analysis of autoantibody titre anti-GAD and C-peptide level was performed. The level of $\mathrm{C}$ peptide was within the normal range, however, very high anti-GAD. In this situation, it should be assumed that diabetes has an autoimmune background. In this situation, it should be assumed that diabetes has an autoimmune background insulin therapy was switched on. In the presence of skin lesions, diagnosis should be considered polyglandular autoimmune syndromes. [32,33]

For confirmation, a series of diagnostic tests would be necessary.

Patient 7. At the time of diagnosis of diabetes, the patient was 72 years old. In view of the very high glycemia, intensive insulin therapy was included. Due to high body weight (BMI 29,7 kg/m2) , metformin was included as an adjunctive therapy. [34 - 39]

A very high anti-GAD titer and a very low level of c-peptide were found. A late-onset autoimmune diabetes was diagnosed (LADA type).

\section{Conclusions}

The cases of patients with diabetes presented above confirm the necessity of introducing new rules for the differentiation of diabetes types. Due to the widening of the diagnostic base, the current classification of diabetes types requires changes.

\section{References}

1. Małecki M, Skupień J. Problems in differential diagnosis of diabetes types. Pol Arch Intern Med. 2008;118(7-8):435-440.

2. Otto Buczkowska E, Jarosz-Chobot P, Machnica L. Diabetes mellitus type 1 , type 2 or type 1.5 - dilemmas in making proper diagnosis. 2008; 8(3):91-94;ISSN 1643-3165 ICID: 878172

3. Thomas CC, Philipson L H. Update on diabetes classification. Med Clin North Am. 2015;99(1):1-16. doi: 10.1016/j.mcna.

4. Zaccardi F, Webb D R, Yates T, Davies M J. Pathophysiology of type 1 and type 2 diabetes mellitus: a 90-year perspective. Postgrad Med J. 2016;92(1084):63-69. doi: 10.1136/postgradmedj-2015-133281.

5. Cheng B W, Lo F S, Wang A M, Hung C M, Huang C Y, Ting W H et al. Autoantibodies against islet cell antigens in children with type 1 diabetes mellitus. Oncotarget. 2018;9(23):16275-16283. doi: 10.18632/oncotarget.24527. 
6. Delic Sarac M, Mutevelic S, Karamehic J, Subasic D, Jukic T, Coric $\mathrm{J}$ et al. ELISA Test for Analyzing of Incidence of Type 1 Diabetes Autoantibodies (GAD and IA2) in Children and Adolescents. Acta Inform Med. 2016;24(1):61-5. doi:10.5455/aim.2016.24.61-65.

7. Chwalba A,Otto-BuczkowskaE. Type LADA (Latent Autoimmunological Diabetes in Adults) as important diagnostic problem in general medical practice: Case presentation. Med Metabol 2015;19(4):34-40 ISSN 1428-1430

8. Huang G, Yin M, Xiang Y, Li X, Shen W, Luo S et al. Persistence of glutamic acid decarboxylase antibody (GADA) is associated with clinical characteristics of latent autoimmune diabetes in adults: a prospective study with 3-year follow-up. Diabetes Metab Res Rev. 2016;32(6):615-622. doi: 10.1002/dmrr.2779.

9. Otto-Buczkowska E., Marciniak-Brzezińska M. [Type LADA diabetes - what does his mean?]. Med. Rodz 2013;16(1):23-26. ISSN 15053768.

10. Otto-Buczkowska E. [The correct diagnosis of LADA type diabetes is still a current problem] Forum Med Rodz 2018;12(1):36-40 ISSN 1897-3590

11. Pozzilli P, Pieralice S. Latent Autoimmune Diabetes in Adults: Current Status and New Horizons. Endocrinol Metab (Seoul). 2018;33(2):147159. doi: 10.3803/EnM.2018.33.2.147.

12. Li R, Huang J, Yu Y, Yang Y. Islet Autoantibody Patterns in Patients With Type 2 Diabetes Aged 60 and Higher: A Cross-Sectional Study in a Chinese Hospital. Front Endocrinol (Lausanne). 2018;9:260. doi: 10.3389/fendo.2018.00260.

13.Zinman B, Kahn S E, Haffner S M, O’Neill M C, Heise M A, Freed M I, ADOPT Study Group. Phenotypic characteristics of GAD antibodypositive recently diagnosed patients with type 2 diabetes in North America and Europe. Diabetes. 2004;53(12):3193-200.

14. Brophy S, Davies H, Mannan S, Brunt H, Williams R. Interventions for latent autoimmune diabetes (LADA) in adults. Cochrane Database Syst Rev. 2011; 9: 1-81. doi: 10.1002/14651858.cd006165

15. Thunander M, Thorgeirsson H, Törn C, Petersson C, Landin-Olsson M. $\beta$-cell function and metabolic control in latent autoimmune diabetes in adults with early insulin versus conventional treatment: a 3-year follow-up. Eur J Endocrinol. 2011; 164(2): 239-245. doi: 10.1530/ EJE-10-0901

16. Daif A, Lukas R V, Issa N P, Javed A, VanHaerents S, Reder A T. et al. Antiglutamic acid decarboxylase 65 (GAD65) antibody-associated epilepsy. Epilepsy Behav. 2018;80:331-336. doi: 10.1016/j. yebeh.2018.01.021.
17. Ben Achour N, Ben Younes T, Rebai I, Ben Ahmed M, Kraoua I, Ben Youssef-Turki I. Severe dysautonomia as a main feature of anti-GAD encephalitis: Report of a paediatric case and literature review. Eur J Paediatr Neurol. 2018;22(3):548-551. doi: 10.1016/j. ejpn.2018.01.004.

18. Galligan A, Xu W, Fourlanos S, Nankervis A, Chiang C, Mant AM. et al. Diabetes associated with immune checkpoint inhibition: presentation and management challenges. Diabet Med. 2018. doi: 10.1111/ dme.13762.

19. Lee S, Morgan A, Shah S, Ebeling P R. Rapid-onset diabetic ketoacidosis secondary to nivolumab therapy. Endocrinol Diabetes Metab Case Rep. 2018. doi: 10.1530/EDM-18-0021.

20. American Diabetes Association. Diagnosis and classification of diabetes mellitus. Diabetes Care. 2014;37(1);81-90. doi: 10.2337/ dc14-S081

21. Maraschin Jde F. Classification of diabetes. Adv Exp Med Biol. 2012;771:12-9

22.Vionnet AC, Jornayvaz FR. [Classification of diabetes: an increasing heterogeneity]. Rev Med Suisse. 2015;11(477):1234-1237.

23. Petreski H. Misdiagnosed patient with latent autoimmune diabetes in adults (case report). Georgian Med News. 2018;(277):31-35.

24. Singla R1, Homko C, Schey R, Parkman HP. Diabetes-related autoantibodies in diabetic gastroparesis. Dig Dis Sci. 2015;60(6):17331737. Doi: $10.1007 / \mathrm{s} 10620-015-3690-0$.

25. Achenbach P, Hawa M, Krause S, Lampasona V, Jerram ST, Williams AJK. et al; Action LADA consortium. Autoantibodies to N-terminally truncated GAD improve clinical phenotyping of individuals with adultonset diabetes: Action LADA 12. Diabetologia. 2018;61(7):1644-1649. Doi: $10.1007 /$ s00125-018-4605-3.

26. Siraj ES, Homko C, Wilson LA, May P, Rao AD, Calles J. et al. Islet Cell Associated Autoantibodies and C-Peptide Levels in Patients with Diabetes and Symptoms of Gastroparesis. Front Endocrinol (Lausanne). 2018;9:32. Doi: 10.3389/fendo.2018.00032.

27. Buzzetti R, Spoletini M, Zampetti S, Campagna G, Marandola L, Panimolle F, et al. Tyrosine phosphatase-related islet antigen 2(256-760) autoantibodies, the only marker of islet autoimmunity that increases by increasing the degree of BMI in obese subjects with type 2 diabetes. Diabetes Care. 2015;38(3):513-520. Doi:10.2337/dc14-1638

28. Li X1, Yang L, Zhou Z, Huang G, Yan X. Glutamic acid decarboxylase 65 autoantibody levels discriminate two subtypes of latent autoimmune diabetes in adults. Chin Med J (Engl). 2003;116(11):1728-1732. 
29. Castleden HA, Shields B, Bingley PJ, Williams AJ, Sampson M, Walker M. et al. GAD antibodies in probands and their relatives in a cohort clinically selected for Type 2 diabetes. Diabet Med. 2006;23(8):834-838.

30. Liu L, Li X, Xiang Y, Huang G, Lin J, Yang L. et al; LADA China Study Group. Latent autoimmune diabetes in adults with low-titer GAD antibodies: similar disease progression with type 2 diabetes: a nationwide, multicenter prospective study (LADA China Study 3). Diabetes Care. 2015;38(1):16-21. Doi: 10.2337/dc14-1770.

31. Martinka E, Rončáková M, Mišániková M, Davani A. [Autoimmune insulitis in patients with type 2 diabetes mellitus A randomized clinical trial in hospitalized patients]. Vnitr Lek. Fall. 2016;62(7-8):521-533.

32. Kahaly GJ, Frommer L. Polyglandular autoimmune syndromes. J Endocrinol Invest. 2018;41(1):91-98. Doi: 10.1007/s40618-017-0740-9.

33. Otto-Buczkowska E., Deja G. [Polygladular autoimmune syndromes.] Physican 2008; 12(5):44-52 ISSN 1896-2920 ICID: 882444

34. Chwalba A, Otto-Buczkowska E. New, pediatric indications for metformin therapy - systematic review. Med Metabol 2016; 20 (3):7377. ISSN $1428-1430$
35. Jacobsen IB, Henriksen JE, Beck-Nielsen H. The effect of metformin in overweight patients with type 1 diabetes and poor metabolic control. Basic Clin Pharmacol Toxicol. 2009;105(3):145-149. Doi: 10.1111/j.1742-7843.2009.00380.x. PMID: 19496776

36. Khan AS, McLoughney CR, Ahmed AB. The effect of metformin on blood glucose control in overweight patients with Type 1 diabetes. Diabet Med. 2006;23(10):1079-1084. PMID: 16978371

37. Moon RJ, Bascombe LA, Holt RI, The addition of metformin in type 1 diabetes improves insulin sensitivity, diabetic control, body composition and patient well-being. Diabetes Obes Metab. 2007;9(1):143-145. PMID: 17199734

38. Otto-Buczkowska E. [Metformin addend to insulin therapy for type 1 diabetes mellitus - based on literature and own experience.] Eur J Clin Exp Med 2010; 8(3):338-342; ISSN 2082-369X ISSN 2082369X ICID: 925110

39. Otto-Buczkowska E, Jainta N. Pharmacological Treatment in Diabetes Mellitus Type 1-Insulin and What Else? Int J Endocrinol Metab 2018;16(1):e13008. Doi: 10.5812/ijem.13008. ISSN: 1726913X 